\title{
An Insight into Female Serial Killers: A Product of Childhood Abuse and Trauma?
}

Ayesha Salman $^{\mathrm{a}}$

\section{${ }^{\mathrm{a}}$ Lahore American School}

The main purpose of this research is an in-depth look into how childhood can affect a person in any way, in particular serial killers. There are a few different types of abuse: psychological, physical, etc., and each of these different types has its own unique effects on a child. However, sometimes patterns can be observed which can link a serial killer's patterns to his/her victim pool and modus operandi. The paper will observe two female serial killers up close and examine the psychological motives behind their heinous crimes and how their childhoods can be linked to their M.O. and victim pool. The paper cites that while there are many differences between these two women, there are also many similarities, some of which can not be directly observed.

Keywords: female, serial killer, criminal, childhood, abuse, trauma, victim, behavior, psychological 


\section{Introduction}

A serial killer is defined to be a characteristic, predictable behavior pattern (Seltzer, 2013). These people's actions are morbidly fascinating to those of us who can't begin to fathom why they do what they do. Most of the time, even the killer is unsure why he/she did what they did other than a burning, overwhelming desire to torture, mutilate, harm, inflict pain, and/or murder. Nearly every single adult who goes on to become a serial killer faced some kind of trauma when he/she was a child, whether that be psychological, physical, emotional, or sexual abuse. The experiences a child goes through during a very young age stick with him/her for his/her entire life and have been shown to have long term effects on the brain. These experiences don't necessarily have to involve abuse. For example, studies have shown that people who were not well-fed as children had lower IQs than those who were fed properly (Jacobsen, 2002). Similarly, people who were breast-fed as children had better relationships with their mothers than those who were fed regular milk. These examples show that childhood definitely has long-lasting effects on people. Although not every child who faced trauma during childhood grows up to become a criminal, almost every serial killer has had a rough time growing up. But is there a correlation between childhood trauma and the patterns that a serial killer (specifically female) exhibits? As a result of this investigation, an analysis of possible treatments or protective factors in order to prevent first or subsequent offenses would not only provide explanation, but also a solution to this type of violence. 
When talking about serial killers, most people think of Ted Bundy, Jeffrey Dahmer, and John Wayne Gacy, three of the most infamous serial killers in history. What do these sinister names have in common? They belong to men. Most people don't believe that women, with their supposedly nurturing and maternal nature, could be responsible for equally heinous crimes. Arguably, the crimes certain female criminals have committed in the past could be seen as worse than those committed by males. While men largely attack strangers, studies have shown that about $80 \%$ of women serial killers know their victims (Kozlowska, 2019). Women tend to kill acquaintances and/or people who surround them. They are often caregivers, and are well-educated.

\section{Links between abusive childhood and becoming a serial murderer}

The World Health Organization (WHO) defines child abuse as "all forms of physical and/or emotional ill-treatment, sexual abuse, neglect or negligent treatment or commercial or other exploitation, resulting in actual or potential harm to the child" (World Health Organization, 1999, p. 80). Although this definition covers a spectrum of abuse, the three main types defined in the present study are physical, sexual, and psychological abuse (Marono, 2020). Physical child abuse relates to acts that cause actual physical harm or have the potential to harm. Sexual abuse is defined as those acts in which a child is used for sexual gratification. Psychological abuse includes the lack of an appropriate and supportive environment or acts that have an adverse effect on the emotional health and development of a child. 
In most cases, biological factors will also contribute to the creation of a killer (Raine, 2008). Dr. Raine also states that people who have a specific variant of the enzyme monoamine-oxidase-A gene are more likely to manifest violent behavior if they had an upbringing with traumatic or violent experiences (Raine, 2013). Neuroscientific research shows that people who suffered some sort of abuse when they were children will likely go on to have less control over their emotions and have worse memories than those who had safe childhoods. According to a study published out of Harvard (Teicher, et al, 2012), being sexually or emotionally abused as a child can stunt the development of three key areas of the hippocampus that control memory and the regulation of emotion. The same study found that $68 \%$ of the serial killers studied were victims of some sort of childhood abuse or trauma. It classified serial killers in terms of their motivations behind their killings. They included the following categories: anger, financial gain, power/lust and rape. Furthermore, there were three categories of child abuse: physical, psychological and sexual.

Serial killers who had been sexually abused during childhood had fantasies of rape/lust and anger murders (Marono, 2020). It was also further linked to overkill (torture, causing unnecessary pain the victim, etc.) necrophilia, and changing the corpse's location from the scene of the crime to somewhere else. Rape/lust and financial gain were linked to killers who had gone through childhood psychologcial abuse. These murders were generally also linked to a pattern of torturing the victim(s). $26 \%$ of serial killers observed in a study were sexually abused compared with the societal proportion of 3\% (Mitchell \& Aamodt, 2005). 
Compared to sexual abuse however, psychological abuse equated to $2 \%$ in the general population as opposed to $50 \%$ in the sample population. It is likely that childhood sexual abuse will lead predominantly to sexual typologies, taking into account previous literature highlighting that violent upbringings influence later delinquency, adult criminality, and violence (Maxfield \& Widom, 1996). A study conducted which examined the association between 4 serial killer typologies (lust/rape, anger, financial gain, and power) and 3 types of childhood abuse (psychological, sexual, and physical) yielded that sexual abuse was potentially connected to the rape/lust and anger typologies (Davies, 2018). Psychological abuse was associated more with rape/lust and financial gain typologies. Acts of crime associated with childhood psychological abuse tended to involve torture (Davies, 2018).

\section{A closer look at infamous female serial killers}

\section{Juana Barraza}

Juana Barraza was born in 1957. She was active from 1998 to 2006, having been found guilty of 16 counts of murder and burglary (and 11 separate counts of murder) in 2008. Formerly a Mexican wrestler, she became known as "La Mataviejitas" (old lady killer) after she strangled and murdered (allegedly) between 42-48 elderly women.

Unsurprisingly, like most criminals, Juana's childhood was traumatic. When Juana was 13 years old, her mother sold her to a man for three beers. Under his care, Juana was a victim of constant abuse and rape and eventually she became pregnant with a son. She went on to become a female wrestler who went by the name "The Silent Lady." She competed in lucha libre matches 
(a form of Mexican masked professional wrestling). This means that although Juana had the physical strength to target younger victims, she deliberately chose older women to be her victim pool.

Barraza started killing in 1998. She lured the victims into a false sense of security by telling them she'd help them with cooking and cleaning. However, once inside, she'd kill them. Her MO was strangulation and sometimes, she would also sexually assault the victim. Police didn't know what to look for as there were no signs of forced entry into the victims' homes. They tried to solve the cases by pulling in relatives and coercing them to confess to a crime they hadn't committed. Since witnesses had seen the victims talking to a woman shortly before their deaths, they believed the killer to be a man dressing up in women's clothes since they never thought a woman would be a serial killer. In order to catch the killer, police set up different raids. They also started fingerprinting everyone in the morgue and comparing the prints to the ones lifted from the crime scene. They believed if it had been a female killer, she would have killed herself after because of the guilt.

Juana Barraza was caught on January 25, 2006 when she was caught red-handed fleeing a crime scene. She had just strangled Ana Maria de los Reyes Alfaro (82) but was caught with the stethoscope she had used to strangle the older woman. In custody, Juana Barraza readily admitted to killing the latest victim and three others but denied most of the other victims. The authorities have reviewed the cases of strangulation in older women, and have estimated that The Old Lady Killer most likely took the lives of 24-49 victims within eight years. 


\section{Psychological motive}

Juana Barraza blames her mother as the reason why she specifically targeted older women as her victims. Since Barraza carried hatred in her heart for her mother, she took it out on women who would have been approximately the same age as her mother would have been at that time. There was also evidence of sexual assault on some of the victims. This might be seen as a way for her to humiliate the victim after death as her primary motive was not sexual. Her anger was displaced, meant for her mother but taken out on innocent older women instead. Juana believed that all elderly women were like her mother, cruel and harmful to society. By killing them, she thought she was doing everyone a favor and ridding the world of their "evil" presence.

\section{Nannie Doss}

One such example is probably the most well known Black Widow Killer. Nannie (birth name: Nancy Hazle) Doss had a rough childhood. Her father ruled over her family with an iron fist and insisted that the children work on the family farm instead of going to school. He also didn't want his daughters wearing anything he considered provocative like makeup or fancy clothes. They also weren't allowed to have friendships with boys. Nannie Doss was 16 the first time she interacted with someone of the opposite sex.

Nannie Doss' primary motive was to collect the life insurance of the people she killed. Being a typical black widow murderer, Nannie Doss killed for profit. Since Nannie Doss's father 
insisted that she not attend school after 6th grade to help out on the farm, she didn't have any way to earn her own money. Also, as seen with people who grew up in abusive households, Nannie went on to have a string of abusive relationships during adulthood as well. Maybe she believed that it would be easier to just kill her four husbands and get their life insurance than stay in abusive relationships. However, this does not explain why she killed her own mother, sister, children, grandchildren, and mother-in-law. It shows a complete lack of remorse for personal relationships and even when asked about her crimes, she would giggle, earning her the nickname the "Giggling Granny." Nannie operated like a typical black widow female serial killer. She only targeted those who were near and familiar to her. She killed much of her own family, showing a complete lack of remorse for even her children.

\section{Psychological motive}

Like most serial killers, Nannie Doss didn't grow up in the most nurturing household. Her father liked to have complete control over his daughters, dictating what they wore and deciding to stop their education. Her mother turned a blind eye to the way Nannie's father used to abuse her and her sister. In effect, she was completely powerless in front of him. Nannie might never have felt strong enough to stand up to her father but she ended up murdering four out of five of her husbands.

Her first husband's mother was very much like Nannie's own father. She was controlling and insisted on living with his son even after he was married. Nannie clearly resented her mother-in-law for being so controlling, perhaps feeling like she could never escape controlling 
people in her life: "I married, as my father wished, in 1921 to a boy I only knowed about four or five months who had no family, only a mother who was unwed and who had taken over my life completely when we were married. She never seen anything wrong with what she done, but she would take spells. She would not let my own mother stay all night..." Nannie later murdered her mother-in-law, maybe because she was tired of being controlled just like her father had controlled her.

Her second husband was an abusive alcoholic and although she learned he had a criminal record a few months into their marriage, she stayed with him for 16 years. During this time, Nannie killed both of her daughter's children. The second, a baby, was killed for unknown reasons. However, the first one was murdered after Nannie had a nasty fight with her daughter, the child's mother. Nannie murdering her own daughter's child after her child defied can be seen as Nannie trying to control her daughter as her own father had controlled her when she was a child. She felt she needed to punish her daughter and so poisoned her children as a result. After her second husband raped her one night in the middle of a drunken stupor, she poisoned him the next day. Once again, this can be seen as Nannie rebelling against control. Her husband violated her without permission, she had been putting up with his abuse for almost two decades, and she finally snapped.

Both her third and fourth husbands were adulterous, and the third was also an alcoholic. Once again, she poisoned them, probably because she felt things were not in her control. As was seen with her daughter, Nannie apparently liked to control everything and rebelled against being 
controlled herself. Her fifth and final husband made the mistake of forbidding Nannie from reading the romance novels she loved. She poisoned him just a few months into their marriage.

Although Nannie killed for profit, her motives could also be seen as displaced anger. She killed those who she felt were exerting control over her in the same way her father had when she was younger. It also looked like she had the same issue her father had: a need to control.

\begin{abstract}
Analysis
Juana Barraza and Nannie Doss were both female serial killers who showed no mercy for humankind. Barraza murdered older women who she had no connection with while Nannie Doss killed her own family members. Both women had difficult childhoods.
\end{abstract}

Barraza's mother gave her away at a young age to a physically and sexually abusive man who often raped her. Barraza was a confrontational killer who murdered her victims by strangulation, a very present method of murder. Barraza's murders fall under the anger typology since she stated on her own that she specifically targeted older women because they reminded her of her mother whom she despised. She murdered in a way as if she wanted to feel her victims' lives leave them. Although her murders were sometimes sexual, she did not murder primarily for sexual motives. She would disarm her victims with her charm and then strangle them with a ligature when they let her into their house. In his study on serial murderers, Godwin (Godwin, 2000) suggested that ligature strangulation represents the killer's expressive rage that 
has a personal focus toward the victim. Juana Barraza felt an extreme amount of hatred towards her mother whom she blamed for her horrific childhood.

Nannie Doss's murders fall under the financial gain typology. Although there are no records of Nannie being physically abused during her childhood, her father James was extremely controlling. The way he treated his children could definitely be identified as psychological abuse. Not letting them wear what they want, see who they want, and preventing them from going to school to work were all ways James would exert control over his children. Nannie's father was controlling and her mother wouldn't do anything to stand up for her children.

\section{Conclusion}

In conclusion, childhood plays a large role in determining how serial killers choose and kill their victims. The type of abuse the killer faced during childhood, be it sexual, psychological, emotional, or physical is a key determining factor in the typology of the murders carried out by the killer. For example, Nannie Doss was psychologically abused by her overly-controlling and oppressive father which is probably why she mainly targeted these types of men. Juana Barraza was angry at her mother her whole life and blamed her for the abuse Juana suffered at the hands of her adoptive father. As a result, she targeted women her mother's age. Both women used different methods to kill. In addition, the way serial killers carry out their crime is also affected by childhood. Since the brain is still developing during childhood, a child's early years play a substantial role in determining the rest of his/her life. 


\section{Bibliography}

1. Bradley, C., \& Moore, C. C. (1996). Sexual division of labor. In D. Levinson \& M. Ember (Eds.), Encyclopedia of cultural anthropology (Vol. 4, pp. 1168-1173). New York, NY: Holt

2. Godwin, G. M. (2000). APA PsycNet. Retrieved July 22, 2020, from https://psycnet.apa.org/record/1999-04373-000

3. Harrison, M. A., Hughes, S. M., \& Gott, A. J. (2019, October). Sex Differences in Serial Killers. Retrieved August 16, 2020, from https://search-proquest-com.ezp.lib.rochester.edu/docview/2170580896/fulltextPDF/1FB D9E6E36A04A8EPQ/1?accountid=13567.

4. Harrison, M. A., Murphy, E. A., Ho, L. Y., Bowers, T. G., \& Flaherty, C. V. (2015). Female serial killers in the United States: Means, motives, and makings. The Journal of Forensic Psychiatry \& Psychology, 26(3), 383-406.

doi:10.1080/14789949.2015.1007516

5. History.com Editors. (2009, November 13). A string of mysterious deaths surrounds a Nebraska woman. Retrieved October 06, 2020, from https://www.history.com/this-day-in-history/a-string-of-mysterious-deaths-surrounds-a-n ebraska-woman

6. Islam, A., Farooq, M., \& Mahmood, B. (2019). Exploring women involvement in crimes in pakistan. Pakistan Journal of Criminology, 11(1), 101-111. Retrieved from 
https://search-proquest-com.ezp.lib.rochester.edu/docview/2308455072?accountid=1356 $\underline{7}$

7. Johnson, S. A. (2019, March 25). Understanding the violent personality: Antisocial personality disorder, psychopathy, \& sociopathy explored. Retrieved July 29, 2020, from https://www.forensicconsultation.org/files/Understanding_the violent_personality_2019. $\underline{\mathrm{pdf}}$

8. Kozlowska, H. (2019, February 25). If male serial killers "hunt" their victims, what do female serial killers do? Retrieved October 5, 2020, from https://qz.com/1556745/the-differences-between-male-and-female-serial-killers/

9. Lax, F. (2018, September 27). A Literature Review on Female Serial Killing: Examining Gendered Features of the Crime. Retrieved October 13, 2020, from https://escholarship.org/uc/item/6qk0h8xv

10. Marono, A., Yaksic, E., \& Keatley, D. (2020, February). (PDF) A Behaviour Sequence Analysis of Serial Killers' Lives: From Childhood Abuse to Methods of Murder. Retrieved August 1, 2020, from https://www.researchgate.net/publication/339078665_A_Behaviour_Sequence_Analysis_ of_Serial_Killers'_Lives_From_Childhood_Abuse_to_Methods_of_Murder

11. Mitchell, H., \& Aamodt, M. G. (2005, March). The incidence of child abuse in serial killers. Retrieved September 08, 2020, from https://ink.springer.com/article/10.1007/BF02806705

12. Norris, J. (2002). Serial killers: The growing menace. Smithfield, N.S.W.: Gary Allen. 
13. Rose, T. W. (2019, May 19). Black Widows, Sexual Predators, and the Reality of Female Serial Killers. Retrieved July 18, 2020, from https://repositories.lib.utexas.edu/bitstream/handle/2152/75503/rosetori_Black\%20Wido ws $\% 2 c \% 20$ Sexual $\% 20$ Predators $\% 2 c \% 20$ and $\% 20$ the $\% 20$ Reality $\% 20$ of $\% 20$ Female $\% 20$ S erial\%20Killers 2019.pdf? sequence $=1 \&$ isAllowed $=y$

14. Teicher, M., Anderson, C., \& Polcari, A. (2012, February 28). Childhood maltreatment is associated with reduced volume in the hippocampal subfields CA3, dentate gyrus, and subiculum. Retrieved July 16, 2020, from https://www.pnas.org/content/109/9/E563 